\title{
THE MECHANISM OF THE ACTION OF THE HYDROGEN ION UPON THE CARDIAC RHYTHM
}

\author{
BY E. COWLES ANDRUS AND EDWARD P. CARTER \\ (From the Cardiographic Laboratory of the Johns Hopkins University and Hospital)
}

(Received for publication September 16, 1926)

It has been abundantly proved that the isolated heart will function normally for some time if it is supplied with an appropriate perfusate. It is also a striking fact that practically all of the abnormalities of rhythm encountered in the clinic are to be observed in the heart isolated from its nerve supply and beating outside the body. Inasmuch as the tissues of the heart can scarcely be thought to undergo any great organic change during the time required in isolating and starting artificial perfusion one is driven to the conclusion that in the development of these abnormal rhythms some other factor than structural damage to the cardiac muscle must play a part.

The question arises as to the similarity in fundamental origin which these abnormalities may have in common with the normal rhythm. The possibility suggests itself that the important factor may be found in some derangement of the metabolism of the cardiac tissue.

Studies of the metabolism of the myocardium have shown it to differ only quantitatively from that of other muscles. Here, as in skeletal muscle, glycogen is broken down into lactic acid which is either resynthesized to glycogen or oxidized to carbon dioxide and water. For the first process oxygen is not required. To the second it is essential. The quantitative differences between heart muscle and skeletal muscle, as shown particularly by the recent work of Katz et al. $(1,2,3)$ in A. V. Hill's laboratory are as follows:

1. The myocardium has far less capacity to "run into debt" for its oxygen.

2. Its buffering power is only one-half that of skeletal muscle.

In such a tissue, alterations in the hydrogen ion concentration are rather to be expected. 
The authors have for some time been engaged in studying the effects of changes in $\mathrm{H}$ ion concentration upon the normal rhythm of the isolated heart. The results of these studies previously reported have shown that it is possible to control the rate of the sinus or nodal rhythm by changes in the $\mathrm{pH}$ of the Locke perfusate between the limits of $\mathrm{pH} 7.0$ and $\mathrm{pH} 7.8$. With a rise in $\mathrm{C}_{\mathrm{H}}$ the propagation of the excitatory process, as represented by the P-R interval, is retarded. When a perfusate is replaced by one slightly more alkaline, auriculoventricular transmission is accelerated (4). Intra-auricular conduction is similarly affected (5). The inhibitory action of the vagus is enhanced at $\mathrm{pH} 7.0$ and decreased by $\mathrm{pH} 7.8$ to 8.0. Sympathomimetic substances, on the other hand, are far more effective at $\mathrm{pH} 7.8$ than at $\mathrm{pH} 7.0$ (6). And finally, the refractory period of both auricular and ventricular muscle has been shown to vary with the reaction of the perfusate, being lengthened at $\mathrm{pH} 7.0$ and shortened at $\mathrm{pH} 7.8$ (7).

Such results would seem to indicate that the hydrogen ion may act to control the normal rhythmic development and transmission of the excitatory process in the heart. It remains to investigate more closely, if possible, the fundamental mechanism of this control.

\section{EFFECT OF CALCIUM}

It has been suggested that changes in $\mathrm{C}_{\mathrm{H}}$ may produce their effects indirectly by effecting the ionization of the calcium. The amount of active calcium ion in such a mixture as Locke's solution is dependent chiefly upon the $\mathrm{pH}$ and the concentration of bicarbonate, decreasing as these factors increase. We have, therefore, undertaken to study the effects of various concentrations of calcium in Locke's solution at the same $\mathrm{pH}$.

The perfusates were prepared with every precaution to insure complete solution of the calcium. $\mathrm{NaCl}, \mathrm{KCl}$, and glucose were dissolved in the usual Locke concentration. This solution was made distinctly acid by bubbling through it a mixture of oxygen and carbon dioxide, and the desired amount of calcium was then added as the chloride. Before the solutions were connected with the perfusing apparatus they were aerated with pure oxygen. The dissolved $\mathrm{CO}_{2}$ was thus driven off and the reaction of the solution finally adjusted 
by the addition of $\mathrm{NaHCO}_{3}$. By this method three perfusates were made up containing respectively, 5, 10 and $15 \mathrm{mgm}$. of calcium per $100 \mathrm{cc}$.

Dogs hearts were perfused through the coronary arteries by the method previously described (1) and galvanometric records taken by direct leads.

TABLE 1

Effect of calcium concentration-5 to $15 \mathrm{mgm}$. per $100 \mathrm{cc}$.

\begin{tabular}{|c|c|c|c|c|}
\hline Time & $\mathrm{Ca}$ & Heart rate & $\mathbf{P}-\mathbf{R}$ & Remarks \\
\hline & mgm. per $100 \mathrm{cc}$. & & seconds & \\
\hline $3: 41$ & 10 & 65 & 0.17 & \\
\hline $3: 42$ & 5 & & & \\
\hline $3: 45$ & 5 & 65 & 0.16 & Heart dilated, contractions \\
\hline $3: 47$ & 5 & 63 & 0.16 & weaker \\
\hline $3: 48$ & 15 & & & \\
\hline 3:49 & 15 & 69 & 0.16 & \\
\hline $3: 51$ & 15 & 63 & 0.16 & Systole augmented \\
\hline $3: 53$ & 15 & 59 & 0.18 & \\
\hline $3: 54$ & 10 & & & \\
\hline $3: 55$ & 10 & 70 & 0.16 & \\
\hline 3:59 & 10 & 71 & 0.16 & \\
\hline 4:00 & 15 & & & \\
\hline 4:01 & 15 & 75 & 0.16 & \\
\hline 4:02 & 15 & 75 & 0.16 & Contractions stronger than in \\
\hline $4: 03$ & 15 & 73 & 0.18 & normal \\
\hline 4:04 & 5 & & & \\
\hline $4: 05$ & 5 & 73 & 0.16 & \\
\hline 4:07 & 5 & 70 & 0.16 & \\
\hline 4:08 & 10 & & & \\
\hline 4:09 & 10 & 71 & 0.16 & \\
\hline $4: 11$ & 10 & 73 & 0.16 & \\
\hline
\end{tabular}

The results of a typical experiment are depicted in table 1. Throughout this study we have been unable to show that such alterations in the total calcium concentration as we have produced have consistently any effect upon the rate of development or transmission of the excitatory process. The amplitude of contraction of the heart muscle is, however, strikingly influenced by these changes. With an increase in the calcium content of the perfusate the beat becomes stronger and systole shorter. A reduction to $5 \mathrm{mgm}$. per 
$100 \mathrm{cc}$. on the other hand causes dilatation of the whole heart and an obvious reduction in the amplitude of contraction.

Andrus and Carter (8) and Daly and Clark (9) have reported an acceleration in rate and shortening of the P-R interval in the coldblooded heart following increase in calcium. More recently Seliskar (10) working in Clark's laboratory has been unable to demonstrate that alterations in calcium content of the perfusate have any effect upon intra-auricular transmission in the turtles heart, although such changes produce obvious differences in contraction. These results are in agreement with those of Langendorff and Hueck (11), who worked with cold and warm-blooded hearts and concluded that calcium was important only to contraction, that it had a very distinct effect in that it augmented the beat, but that it was without influence on the rate.

TABLE 2

Effect of phosphoric and carbonic acids on auricular rate

\begin{tabular}{c|c|c}
\hline & \multicolumn{2}{|c}{ Auricular rate } \\
\cline { 2 - 3 } & Solution I & Solution II \\
\hline 7.8 & 168 & 168 \\
7.6 & 162 & 168 \\
7.4 & 159 & 166 \\
7.2 & 150 & 162 \\
7.0 & 140 & 155 \\
\hline
\end{tabular}

It seems, therefore, unlikely that the effects of alterations in $\mathrm{H}$ ion concentration are to be explained by the resultant changes in the ionization of calcium. Indeed such positive effects as have been reported seem directly opposed to such a conclusion, since an increase in calcium has, if any, an augmentatory action whereas increase in $\mathrm{H}$ ion concentration is per se consistently depressant.

\section{EFFECT OF $\mathrm{H}_{2} \mathrm{CO}_{3}$}

In the course of a series of experiments upon the isolated rabbits auricles reported by one of us (6) it was found that equal changes in $\mathrm{pH}$ produced quantitatively different effects upon the rhythm depending upon the acid employed. These results are shown in the 
accompanying table 2. Solution I was buffered with phosphate and the changes in $\mathrm{pH}$ were produced with phosphoric acid. Solution II contained bicarbonate as the buffer and its reaction was controlled by the concentration of $\mathrm{CO}_{2}$ bubbled through it.

In explanation of the fact that the solution containing phosphoric acid was far more effective in depressing the rate than the perfusate

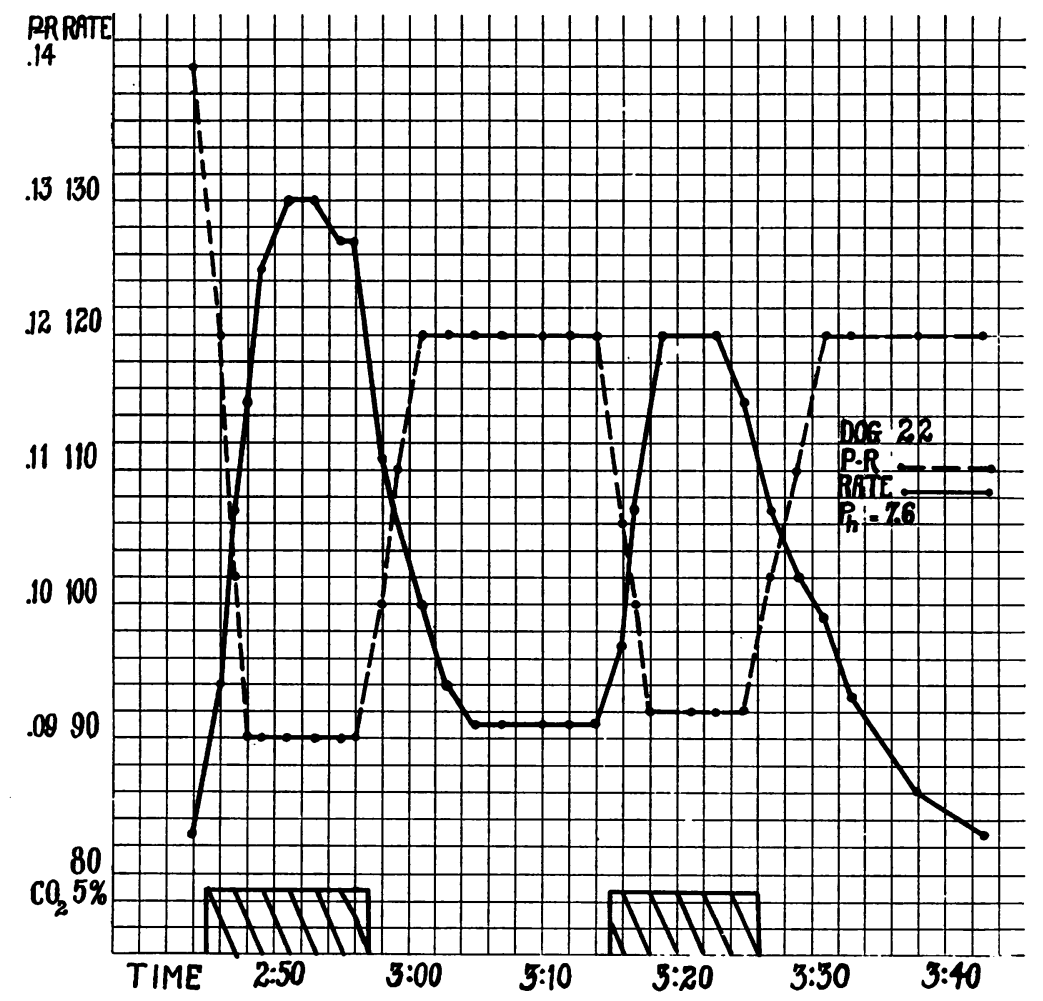

Fig. 1. The Effect of a Perfusate Containing $\mathrm{CO}_{2}$ upon the Excitatory Process IN THE Dog's Heart

containing $\mathrm{CO}_{2}$, it was suggested at the time that changes in the $\mathrm{H}$ ion concentration of the perfusing fluid when produced by carbonic acid were reflected in the $\mathrm{C}_{\mathrm{H}}$ of the cell content to a greater extent than were similar alterations brought about by phosphoric acid.

These results led us to investigate the effects upon the rhythm of different concentrations of carbonic acid at the same $\mathrm{pH}$. The 
hearts of dogs were perfused with two types of Locke's solution. The first was aerated with pure oxygen and its $\mathrm{pH}$ adjusted by the addition of $\mathrm{NaHCO}_{3}$. The second solution was aerated with a mixture of oxygen 95 per cent and carbon dioxide 5 per cent. Samples of this solution were titrated in an atmosphere of the $\mathrm{CO}_{2}-\mathrm{O}_{2}$ mixture in order to determine the amount of $\mathrm{NaHCO}_{3}$ necessary to keep the $\mathrm{pH}$ at the desired level. Excess of $\mathrm{Na}$ ion was then compensated by reducing the amount of $\mathrm{Na}$ added as the chloride.

When the heart is perfused with a solution containing carbonic acid the effects upon rate and transmission are very similar to those resulting upon a change from normal to a more alkaline perfusate. Thus in the experiment illustrated in figure 1 , when the $\mathrm{H}_{2} \mathrm{CO}_{3}$-con-

TABLE 3

Effect of $\mathrm{CO}_{2}$ upon rate and conduction. pH 7.2

\begin{tabular}{c|c|c|c}
\hline Time & $\mathrm{CO}_{2}$ & Heart rate & P-R \\
\cline { 2 - 3 } $2: 53$ & per cent & & seconis \\
$2: 56$ & 0 & 67 & 0.28 \\
$2: 57$ & 5 & 68 & 0.22 \\
$2: 58$ & 5 & 75 & 0.18 \\
$2: 59$ & 5 & 81 & 0.18 \\
$3: 02$ & 5 & 81 & 0.18 \\
$3: 04$ & 0 & 68 & 0.24 \\
$3: 08$ & 0 & 65 & 0.30 \\
\hline
\end{tabular}

taining perfusate was substituted for one of the same $\mathrm{pH}$ (7.6) aerated with pure oxygen there was a steady rise in the rate of beat and concomitantly a shortening of the P-R interval. In table 3 are shown the results of a similar experiment carried out at $\mathrm{pH}$ 7.2. Here, due to the lower $\mathrm{pH}$ of the perfusate, the rate is slower throughout and the P-R interval longer but the same type of effect is to be noted as in the previous observation. Such results are consistently obtained, although in a certain proportion of experiments the alterations in rate come on somewhat more slowly than those resulting from a change from normal to a more alkaline perfusate, and tend to pass off more gradually upon return to the first solution.

Experiments were also carried out to determine the effects of 
E. COWLES ANDRUS AND EDWARD P. CARTER

TABLE 4

Influence of $\mathrm{CO}_{2}$ on transmission in auricle

\begin{tabular}{|c|c|c|c|c|c|}
\hline Experiment & Time & $\mathrm{pH}$ & Auricular rate & Perfusate & Transmission \\
\hline \multirow{5}{*}{31} & & & & & $m m$. per second \\
\hline & $3: 32$ & 7.6 & 125 & $\mathrm{O}_{2}$ & 952 \\
\hline & $3: 36$ & 7.6 & 125 & $\mathrm{O}_{2}$ & 851 \\
\hline & $3: 44$ & 7.6 & 125 & $\mathrm{CO}_{2}, 5$ per cent & 1030 \\
\hline & $3: 47$ & 7.6 & 125 & $\mathrm{CO}_{2}, 5$ per cent & 1090 \\
\hline \multirow{9}{*}{34} & $3: 50 \frac{1}{2}$ & 7.5 & 190 & $\mathrm{O}_{2}$ & 859 \\
\hline & $3: 52$ & 7.5 & 190 & $\mathrm{O}_{2}$ & 853 \\
\hline & $3: 55$ & 7.5 & 190 & $\mathrm{CO}_{\mathfrak{l}}, 5$ per cent & 1080 \\
\hline & $3: 57$ & 7.5 & 190 & $\mathrm{CO}_{2}, 5$ per cent & 1220 \\
\hline & 4:09 & 7.5 & 190 & $\mathrm{O}_{2}$ & 955 \\
\hline & $4: 10 \frac{1}{2}$ & 7.5 & 190 & $\mathrm{O}_{2}$ & 800 \\
\hline & $4: 13$ & 7.5 & 190 & $\mathrm{CO}_{\ddot{2}}, 5$ per cent & 855 \\
\hline & $4: 14$ & 7.5 & 190 & $\mathrm{CO}_{2}, 5$ per cent & 934 \\
\hline & $4: 16$ & 7.5 & 190 & $\mathrm{CO}_{2}, 5$ per cent & 955 \\
\hline \multirow{12}{*}{35} & $2: 55$ & 7.2 & 150 & $\mathrm{O}_{2}$ & 500 \\
\hline & $2: 56$ & 7.2 & 150 & $\mathrm{O}_{2}$ & 500 \\
\hline & $2: 58$ & 7.2 & 150 & $\mathrm{CO}_{2}, 5$ per cent & 890 \\
\hline & 3:01 & 7.2 & 150 & $\mathrm{CO}_{2}, 5$ per cent & 920 \\
\hline & $3: 02$ & 7.2 & 150 & $\mathrm{CO}_{2}, 5$ per cent & 970 \\
\hline & $3: 03 \frac{1}{2}$ & 7.2 & 150 & $\mathrm{CO}_{2}, 5$ per cent & 900 \\
\hline & $3: 04 \frac{1}{2}$ & 7.2 & 150 & $\mathrm{CO}_{\varepsilon}, 5$ per cent & 950 \\
\hline & 3:07 & 7.2 & 150 & $\mathrm{O}_{2}$ & 765 \\
\hline & $3: 08$ & 7.2 & 150 & $\mathrm{O}_{2}$ & 700 \\
\hline & $3: 09$ & 7.2 & 150 & $\mathrm{O}_{2}$ & 675 \\
\hline & $3: 10 \frac{1}{2}$ & 7.2 & 150 & $\mathrm{O}_{2}$ & 660 \\
\hline & $3: 11 \frac{1}{2}$ & 7.2 & 150 & $\mathrm{O}_{2}$ & 660 \\
\hline \multirow{9}{*}{37} & $2: 54$ & 7.1 & 125 & $\mathrm{O}_{2}$ & 560 \\
\hline & $2: 55$ & 7.1 & 125 & $\mathrm{O}_{2}$ & 530 \\
\hline & $2: 57 \frac{1}{2}$ & 7.1 & 125 & $\mathrm{CO}_{2}, 5$ per cent & 975 \\
\hline & $2: 59$ & 7.1 & 125 & $\mathrm{CO}_{2}, 5$ per cent & 800 \\
\hline & $3: 01$ & 7.1 & 125 & $\mathrm{CO}_{2}, 5$ per cent & 825 \\
\hline & 3:04 & 7.1 & 125 & $\mathrm{O}_{2}$ & 660 \\
\hline & $3: 05 \frac{1}{2}$ & 7.1 & 125 & $\mathrm{O}_{2}$ & 610 \\
\hline & 3:07 & 7.1 & 125 & $\mathrm{O}_{2}$ & 590 \\
\hline & $3: 08$ & 7.1 & 125 & $\mathrm{O}_{i}$ & 550 \\
\hline
\end{tabular}

carbonic acid upon conduction in the auricular muscle. The heart was slung in the pericardium to the thoracic walls and the right auricle was stretched out and held by means of a thread attached to 
the tip of the auricular appendix. Pairs of non-polarizable electrodes were placed in line in contact with the auricular muscle and each pair connected with a galvanometer string. The heart was driven at a constant rate by rhythmic break shocks applied to the base of the auricle. Perfusion was carried out with the solutions described above. In a series of experiments the rate of transmission of the excitatory process in the auricle was consistently accelerated by a perfusate containing carbonic acid, as illustrated in table 4 . Here, again is seen a gradual return to the normal rate when the oxygensaturated perfusate replaces that containing carbonic acid.

\section{DISCUSSION}

In earlier publications the authors have suggested that the fundamental mechanism in the control of the cardiac rhythm is dependent upon the difference in $\mathrm{H}$ ion concentration between cells themselves and the fluid bathing them. It is as if the effect of a fall in $\mathrm{pH}$ in the perfusion fluid were due to a reduction in the essential gradient necessary to the spontaneous development of excitation. Conversely, a rise in alkalinity of the perfusing fluid, by increasing this difference, enhances both rate and "conduction." Moreover, the fact that "conduction" is also influenced by such changes supports the view that transmission of the excitatory process depends upon the excitation of adjacent tissue by the local process at each excited point.

Considerable evidence has accumulated indicating that carbonic acid or its ions exert a specific effect upon various tissues and that this property may have to do with the ability of this acid or its ions to penetrate the cell and to raise the $\mathrm{H}$ ion concentration of its contents. This evidence is summarized in a recent paper by Smith (12) who has studied the action of various acids upon the heart muscle of the turtle with special reference to the penetration of anions. The cells of the turtle's auricle, are, apparently, permeable to $\mathrm{CO}_{2}$ but impermeable to the ions of phosphoric or hydrochloric acid. $\mathrm{H}$ ion penetrates atrial tissue only when its concentration in the tissue fluid is well above that in the cell and "in comparison with the rapid penetration of $\mathrm{CO}_{2}$, the penetrating power of the hydrogen ion, the primary phosphate ion and lactic acid is almost negligible."

The effects of carbonic acid upon the rhythmic development and 
transmission of the excitatory process may, therefore, be due to an increase in the difference in $\mathrm{C}_{\mathrm{H}}$ within and without the cell secondary to the rise in intra-cellular $\mathrm{H}$ ion concentration. Except for the fact that these effects are less rapid in their onset and tend to persist for a certain period after the withdrawal of the $\mathrm{CO}_{2}$-due possibly to conditions of diffusion,- - they are identical with those obtained by changing from a normal to a more alkaline perfusate. Here again, the acceleration is, apparently, associated with an increase in the difference in $\mathrm{H}$ ion concentration within and without the cell.

An alternative to this explanation should be mentioned. The carbonic acid-containing solution has, obviously, by virtue of its greater bicarbonate content, a greater buffer power than the normal Locke's solution. It may, therefore, act by virtue of its potential alkalinity. In either case, however, the $\mathrm{C}_{\mathrm{H}}$ of the cell itself as opposed to that of its environment would appear to be the factor controlling the rhythm.

\section{SUMMARY AND CONCLUSIONS}

The effects upon the rhythm of the dog's heart of changes in $\mathrm{C}_{\mathrm{H}}$ of the perfusing fluid are not due to alterations in the ionization of calcium.

An increase in the carbonic acid content of the perfusate, brought about without change in $\mathrm{pH}$, accelerates the spontaneous development and propagation of the excitatory process.

The authors conclude, therefore, that the cardiac tissue is peculiarly sensitive to alterations in hydrogen ion concentration, whether this occurs in the cell itself through products of its own metabolism or by alterations in the $\mathrm{pH}$ or $\mathrm{CO}_{2}$ content of the fluid bathing it, and suggest that the difference in hydrogen ion concentration within and without the cell is the factor controlling its excitation. Studies are now under way to determine the rôle of such changes in the production and control of abnormal rhythms.

\section{BIBLIOGRAPHY}

1. Katz, L. N., and Long, C. N. H.: Proc. Roy. Soc., Series B, 1926, xcix, 8. Lactic Acid in Mammalian Cardiac Muscle. Part I. The Stimulation Maximum. 
2. Hines, H. J. C., Katz, L. N., and Long, C. N. H.: Proc. Roy. Soc., Series B, 1926, xcix, 20. Lactic Acid in Mammalian Cardiac Muscle. Part II. The Rigor Mortis Maximum and the Normal Glycogen Content.

3. Katz, L. N., Kerridge, P. I., and Long, C. N. H.: Proc. Roy. Soc., Series B, 1926, xcix, 26. Part III. Changes in Hydrogen Ion Concentration.

4. Andrus, E. C., and Carter, E. P.: Heart, 1924, xi, 97 . The Development and Propagation of the Excitatory Process in the Perfused Heart.

5. Drury, A. M., and Andrus, E. C.: Heart, 1924, xi, 389. The Influence of Hydrogen-Ion Concentration upon Conduction in the Auricle of the Perfused Mammalian Heart.

6. Andrus, E. C.: Jour. Physiol., 1925, lix, 361. The Effect of Certain Changes in the Perfusate upon the Isolated Auricles of the Rabbit.

7. Carter, E. P., and Dieuaide, F. R.: Johns Hopkins Hosp. Bull., 1926, xxxix, 99. The Influence of Changes in Hydrogen Ion Concentration upon the Refractory Period of the Perfused Mammalian Heart.

8. Andrus, E. C., and Carter, E. P.: Amer. Jour. Physiol., 1922, lix, 227. The Effect upon the Cold-blooded Heart of Changes in the Ionic Content of the Perfusate.

9. Daly, I. de B., and Clark, A. J.: Jour. Physiol., 1921, liv, 367. The Action of Ions upon the Frog's Heart.

10. Seliskar, A.: Jour. Physiol., 1926, lxi, 172. The Action of Ions upon Intraauricular Conduction in the Tortoise.

11. Langendorff, O., and Hueck, W.: Arch. f. d. ges. Physiol., 1903, xcvi, 473. Die Wirkung des Calcium auf das Herz.

12. Smith, H. W.: Amer. Jour. Physiol., 1926, lxxvi, 411. The Action of Acids on Turtle Heart Muscle with Reference to the Penetration of Anions. 